The Polish Journal of the Arts and Culture. New Series 12

(2/2020): 143-148 [UWAGI]

\title{
Polskie akcenty w Albanii w okresie Odrodzenia Narodowego (Rilindja Kombëtare)
}

\section{Leonard ZissI}

Albania, która przez 500 lat znajdowała się pod panowaniem Turków osmańskich, niepodległość uzyskała dopiero w roku 1912. Przełom XIX i XX wieku to szczytowy okres dla ruchu niepodległościowego na rzecz wyzwolenia Albanii (alb. Rilindja Kombëtare). W czasie Rilindja (1836-1912) nastąpił bogaty rozwój literatury albańskiej, zaczęto wydawać prasę, pod koniec XIX wieku otwarto pierwszą szkołę w języku albańskim, a poza granicami Albanii powstawały stowarzyszenia kulturalno-oświatowe. To twórcze ożywienie podporządkowane było fundamentalnej wówczas idei narodowowyzwoleńczej.

Na okres ten przypada działalność Ndre Mjedy SJ (1866-1937), jednego z najbardziej znanych poetów i patriotów albańskich. Wprawdzie jego życiu i twórczości literackiej poświęcono wiele publikacji w języku albańskim, w których wspominano wątek polski, ale żadna z nich nie wychodziła poza ogólne stwierdzenia i tym samym nie zwracała uwagi na jego niebagatelne znaczenie na późniejsze wybory Mjedy oraz jego aktywność literacką i społeczną.

W latach 1881-1894 Prowincja Wenecka Towarzystwa Jezusowego wysłała na studia teologiczne do Krakowa, do znanego wówczas ośrodka naukowego Prowincji Galicyjskiej przy ul. Kopernika ${ }^{1}$, 40 kleryków, wśród których był Ndre Mjeda. Towarzyszył mu drugi Albańczyk, Antonio Maria Zanoni (1862-1915). Ndre Mjeda studiował w Krakowie teologię moralną i dogmatyczną w latach 1891-1893. Mimo stosunkowo krótkiego pobytu na ziemiach polskich pod zaborem austriackim, właśnie te lata zaważyły na jego formacji

1 Swoimi początkami krakowskie kolegium jezuickie przy ul. Kopernika 26 sięga 1868 roku. 
duchowej i intelektualnej. Po powrocie do Albanii, zarówno Ndre Mjeda, jak i Antonio Maria Zanoni, wnieśli duży wkład w odradzanie się albańskiej kultury literackiej i budowanie wśród swoich rodaków świadomości narodowej ${ }^{2}$.

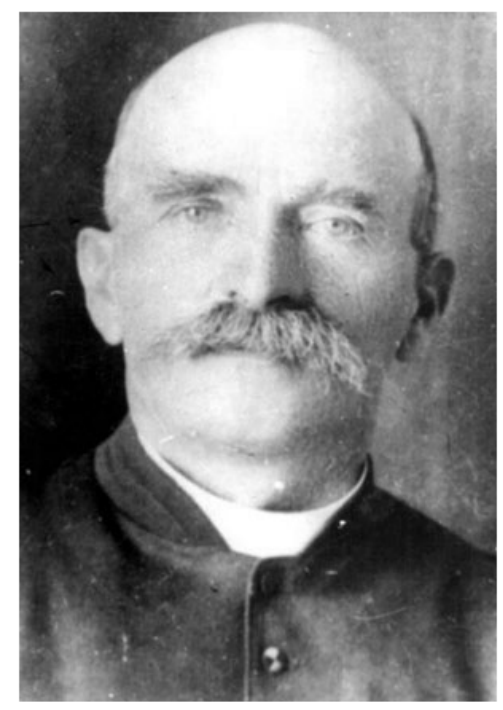

Ryc. 1. Ndre Mjeda

Będąc w Krakowie, Ndre Mjeda zapoznał się z pracami wybitnych albanologów, Holgera Pedersena oraz Gustava Meyera, i rozpoczął z nimi ożywioną korespondencję ${ }^{3}$. Obaj badacze zajmowali się kwestiami języka albańskiego. To dzięki nim Ndre Mjeda - świadomy kulturotwórczej roli języka i widząc w nim nadrzędny symbol narodowości - podjął wysiłki zmierzające do podniesienia znajomości albańskiego w swoim narodzie, a także wprowadzania i upowszechniania ustandaryzowanego albańskiego alfabetu ${ }^{4}$.

2 Zanoni po powrocie do Albanii przygotował publikację poświęconą gramatyce języka albańskiego.

3 W Krakowie napisał wiersz Gjuha shqype (,Język albański”), który zadedykował Gustavowi Meyerowi.

4 Zarówno Meyer w swojej pracy Etymologisches Wörterbuch der albanischen Sprache (1892), jak i Pedersen w Albanesische Texte mit Glossar (1895) wykorzystali zapis alfabetyczny opracowany przez Kostandina Kristoforidhiego (zm. 1895), albańskiego pisarza, pierwszego tłu- 


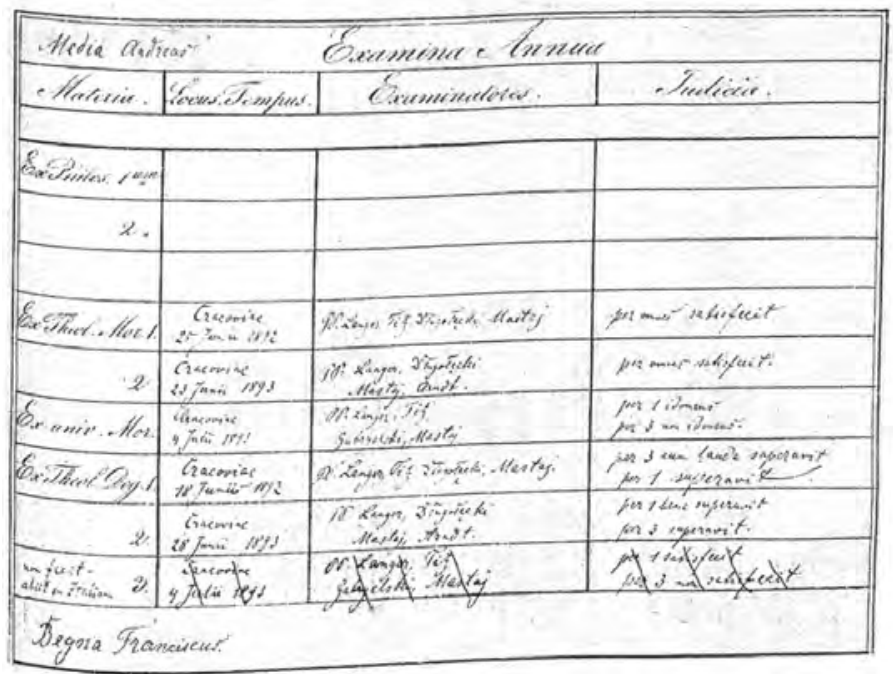

Ryc. 2. Karta egzaminacyjna Ndre Mjedy z teologii moralnej i dogmatycznej w kolegium jezuickim w Krakowie (materiały Archiwum Prowincji Polski Południowej Towarzystwa Jezusowego)

Także tutaj, w Krakowie, poznał „ojca polskiej misjologii”, Marcina Czermińskiego SJ (1860-1931), który od 1889 roku był redaktorem miesięcznika ilustrowanego „Misje Katolickie”. Czasopismo poświęcone było katolickim misjom zagranicznym, m.in. tym prowadzonym na Bałkanach. Sam Czermiński odwiedził Albanię, Dalmację, Czarnogórę, Bośnię i Hercegowinę, Chorwację oraz Grecję. Owocem podróży na Bałkany jest kilka książek. Jedna $\mathrm{z}$ nich to Albania. Zarysy etnograficzne, kulturalne i religijne ${ }^{5}$, przy pisaniu której współpracował właśnie z Ndre Mjedą. Praca jest bardzo cenną pozycją, nie tylko ze względu na barwne opisy obyczajów i historii kraju, ale przede wszystkim z racji przenikliwości autora w obserwacji uwarunkowań społecznych i kulturowych dla rozwoju chrześcijaństwa. Po ponad 120 latach książka doczekała się przekładu na język albański ${ }^{6}$. Była to pierwsza w dorobku Czermińskiego książka przetłumaczona na język obcy (podczas wizyty

macza Nowego Testamentu na dialekt gegijski, autora słownika albańskiego i wielu materiałów edukacyjnych. Oficjalnie alfabet łaciński, dostosowany do fonologii języka albańskiego, został wprowadzony w 1908 roku (wcześniej do zapisu wykorzystywano alfabet grecki, cyrylicę, a nawet arabski).

5 Wydana w Krakowie w 1893 roku w drukarni „Czasu” Fr. Kluczyckiego i Spółki.

${ }^{6}$ Marcin Czermiński, Shqipëria. Përshkrime historike, etnografike, kulturore dhe fetare, Përkthyesi Leonard Zissi, Onufri, Tiranë 2014. 
papieża Franciszka w Albanii, we wrześniu 2014 roku, nuncjusz apostolski w tym kraju, arcybiskup Ramiro Moliner Inglés, wręczył papieżowi albański egzemplarz tej książki).

Droga do poznania tego nieopracowanego do niedawna okresu w życiu Ndre Mjedy była długa. Ze względu na jego zasługi dla ojczystej kultury, władze albańskie zwróciły się do mnie o pomoc w znalezieniu ewentualnych dokumentów o pobycie Ndre Mjedy w Krakowie. Napisałem list z prośbą o pomoc do byłego dyrektora Archiwum Prowincji Polski Południowej Towarzystwa Jezusowego, ks. dra Bogusława Steczka SJ. W odpowiedzi otrzymałem aż osiem dokumentów dotyczących pobytu Ndre Mjedy w kolegium jezuickim, kształcenia, wyników uzyskanych w nauce itd. Jak mówi ks. Steczek w wypowiedzi dla filmu albańskiej TV o Ndre Mjeda:

Zachowały się między innymi stopnie z egzaminów, jakie Ndre Mjeda zdawał podczas swoich studiów teologicznych w krakowskim Kolegium jezuitów, a także diariusze opisujące codzienne życie mieszkańców Kolegium profesorów i studentów. Również doroczne Katalogi jezuickiej Prowincji rejestrowały pobyt Ndre Mjedy, a także innych młodych jezuitów z Weneckiej Prowincji zakonu, do której on należał. Przesłałem kopie dokumentów do Tirany.

Dokumenty te opublikowałem po raz pierwszy w gazecie albańskiej "Gazeta Shqiptare” (01.08.2018) w związku ze 152 rocznicą urodzin poety. Ks. Steczek poradził mi także nawiązać kontakt z ks. dr. hab. prof. AIK Stanisławem Cieślakiem SJ, który był wówczas zaangażowany w realizację projektu naukowego poświęconego jezuitom z Prowincji Weneckiej Towarzystwa Jezusowego. Owocem jego pracy było opracowanie biograficzno-historyczne Ndre Mjeda i inni jezuici Prowincji Weneckiej w Krakowie, które przetłumaczyłem na język albański ${ }^{7}$.

Książka ks. Cieślaka wypełniła lukę w badaniach historycznych i w biografistyce okresu Rilindja, ale nie tylko. Wzbogaciła także świadomość własnej tożsamości Albańczyków i przybliżyła środowisko duchowe i intelektualne, które twórczo oddziałało na Ndre Mjedę w najbardziej istotnym dla

7 Ndre Mjeda dhe fezuitët e tjerë të Provincës së Venecies në Krakov, Përkthyesi Leonard Zissi, Hyrja nga Leonard Zissi, Parathënia nga Dom Nik Ukgjini, Botimet Flesh, Tiranë 2018. Książka trafiła do bibliotek naukowych w Albanii, Polsce i w Rzymie (Pontificia Università Gregoriana, Archivum Romanum Societatis Iesu). Została też wysłana do różnych instytucji naukowych, władz Kościoła katolickiego w Albanii i przedstawicieli dyplomatycznych w Tiranie. 
niego momencie życia. Wreszcie zwróciła uwagę na wzajemne powiązania obu krajów w indywidualnych losach Polaków i Albańczyków.

Dość powiedzieć, że do tego okresu z życia naszego wielkiego poety, duszpasterza i polityka odwołano się już w listopadzie 2018 roku, przy okazji corocznie obchodzonych „Dni Ndre Mjedy” w miejscowości Kukël, gdzie pod koniec życia Mjeda sprawował funkcję proboszcza ${ }^{8}$. W kolejnym roku, z inicjatywy Albańskiego Instytutu Studiów Międzynarodowych w Tiranie, zorganizowano sympozjum poświęcone stosunkom albańsko-polskim ${ }^{9}$. W czerwcu 2019 roku reżyser Ylli Pepo i operator zdjęć Xhemal Reçi, zainspirowani polskim wątkiem w życiu Mjedy, przyjechali do Polski, by nagrać materiał filmowy do opowieści o Ndre Mjedzie, gdzie głównym konsultantem był ks. Cieślak. Filmowcom przyświecała również idea, aby przybliżyć albańskiemu odbiorcy Kraków, Akademię Ignatianum oraz kolegium jezuickie w Krakowie.

Inicjatywy te pokazują, że warto prowadzić dalsze badania nad „polskimi akcentami” w Albanii, nie tylko okresu Rilindja. W tym kontekście należy dopowiedzieć, że literatura albańska o Polsce i literatura polska w Albanii ma już całkiem długą tradycję. Książka ks. Cieślaka, podobnie jak prace ks. Czermińskiego, a także wiele przykładów polskiej literatury pięknej (w Albanii ukazały się przekłady prawie 60 dzieł polskich autorów, między innymi Henryka Sienkiewicza, Adama Mickiewicza, Czesława Miłosza, Wisławy Szymborskiej, Olgi Tokarczuk, Ryszarda Kapuścińskiego, Tadeusza Różewicza, Sławomira Mrożka), „otwiera - zdaniem prof. Tadeusza Czekalskiego nowe perspektywy badań związków dwóch narodów, które mimo geograficznego oddalenia nie zerwały kontaktów sięgających XV w. i wspólnej walki przeciwko Turcji Osmańskiej”10.

8 W ramach „Dni” objętych patronatem Centrum Muzealnego Ndre Mjedy w Kukël i Wydziału Nauk Społecznych Uniwersytetu w Szkodrze uczniowie szkół średnich Szkodry przygotowali specjalny program artystyczny połączony z recytacją wierszy poety napisanych dla dzieci i młodzieży. W „Dniach” brali udział przedstawiciele władz miejskich i kościelnych, profesorowie z Uniwersytetu Tirany i Szkodry, a także z Kosowa i Czarnogóry. Jednym z punktów programu była promocja książki ks. Cieślaka.

9 Wystąpiłem tam z referatem poświęconym w dużej mierze znajomości literatury polskiej w Albanii, pt. „Stosunki albańsko-polskie wczoraj, dziś i jutro.”

${ }^{10}$ Tadeusz Czekalski, Stanisław Cieślak SJ, Ndre Mjeda dhe jezuitët e tjerë të Provincës së Venecies në Krakov, tłum. Leonard Zissi, (Ndre Mjeda i inni jezuici z Prowincji Weneckiej w Krakowie), Tirana 2018, ss. 192, „Balcanica Posnaniensia. Acta et studia” XXV (2018), s. 332. 
ZISSI, Polskie akcenty w Albanii w okresie Odrodzenia Narodowego... 148

\section{Nota o autorze}

Leonard Zıssi, tłumacz literatury polskiej na język albański. Honorowy Prezes Towarzystwa Przyjaźni Albańsko-Polskiej. 